This item was submitted to Loughborough's Research Repository by the author.

Items in Figshare are protected by copyright, with all rights reserved, unless otherwise indicated.

\title{
The tax treatment of employer commuting support: an international review
}

PLEASE CITE THE PUBLISHED VERSION

PUBLISHER

(C) Taylor \& Francis

LICENCE

CC BY-NC-ND 4.0

\section{REPOSITORY RECORD}

Potter, Stephen, Marcus P. Enoch, Tom Rye, Colin Black, and Barry Ubbels. 2019. "The Tax Treatment of Employer Commuting Support: An International Review”. figshare. https://hdl.handle.net/2134/3330. 
This item was submitted to Loughborough's Institutional Repository by the author and is made available under the following Creative Commons Licence conditions.

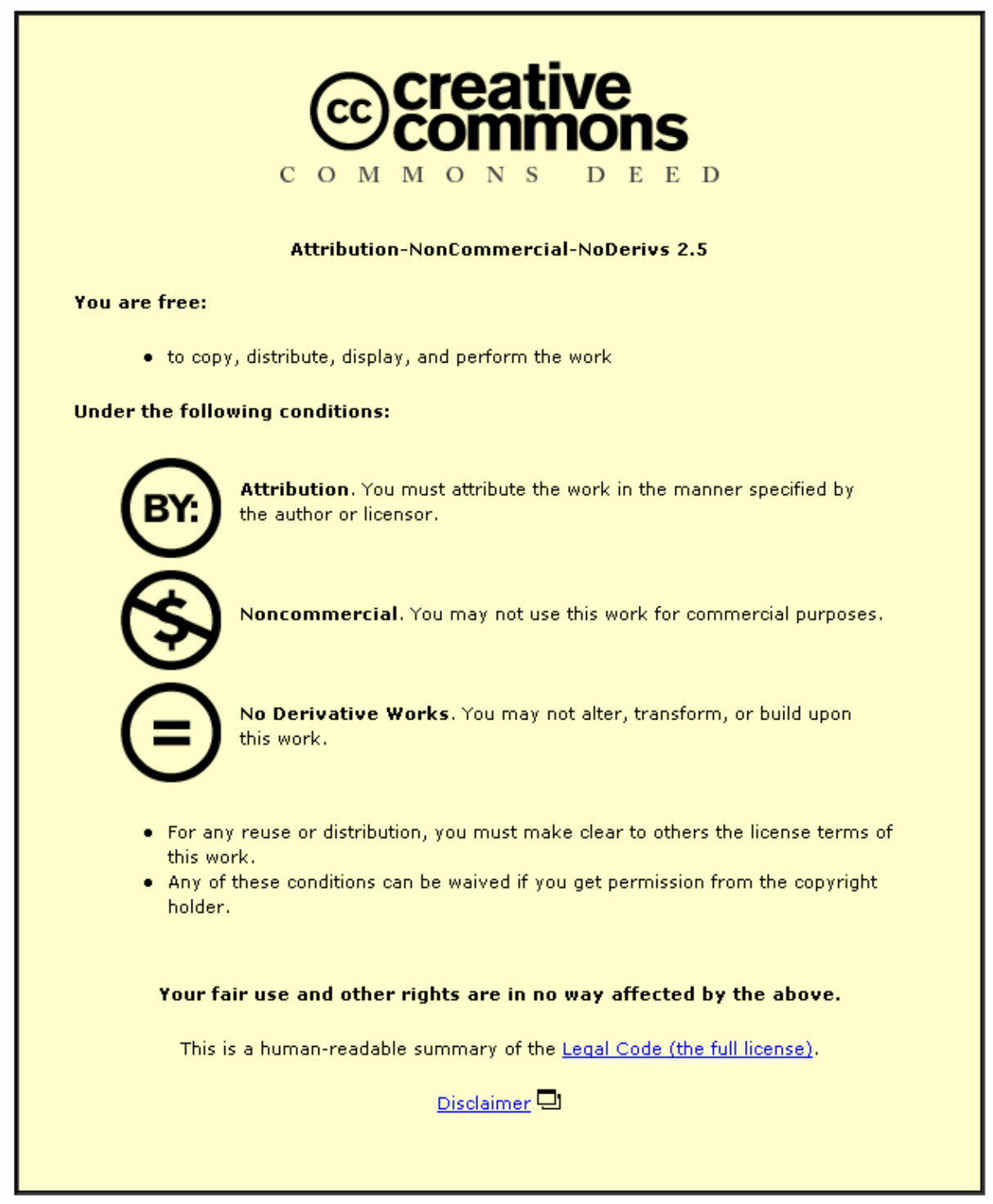

For the full text of this licence, please go to: http://creativecommons.org/licenses/by-nc-nd/2.5/ 


\title{
The tax treatment of employer commuting support: an international review
}

Dr Stephen Potter, Centre for Technology Strategy, The Open University, Milton Keynes, England, MK7 6AA. Tel: +44 (0)1908 652634. Fax: +44 (0)1908 654052, Email: s.potter@open.ac.uk.

Dr Marcus Enoch", Dept of Civil and Building Engineering, Loughborough University, Leicestershire LE11 3TU Tel: +44 (0) 1509 223408. Fax: +44 (0)1509 223981, Email: m.p.enoch@lboro.ac.uk.

Dr Tom Rye, Transport Research Institute, Napier University, School of the Built Environment, 10 Colinton Road, Edinburgh, Scotland, EH10 5DT. Tel: +44 (0) 1314552210 Fax: +44 (0) 131455 2239, Email: t.rye@napier.ac.uk.

Dr Colin Black, JMP Consultants, 172 Tottenham Court Road, London W1T 7NA, Great Britain. Tel +44 (0) 207388 5331, Fax: 0207387 0078, Email: colin.black@jmp.co.uk

Mr Barry Ubbels, Faculty of Economics and Business Administration, Department of Spatial Economics, Free University Amsterdam, De Boelelaan 1105, 1081 HV Amsterdam, The Netherlands. Tel: +31 20444 6088, Fax: +31 20444 6004, Email: bubbels@feweb.vu.nl.

\begin{abstract}
Correctly pricing transport behaviour to take account of the 'external' costs such as congestion, and emissions imposed on society by excessive car use has long been a tenet of effective Transportation Demand Management. But while policy makers have striven to increase public transport subsidies, raise petrol taxes, and introduce road user charging schemes to properly price the real costs of car travel, in most cases correcting the wider influences of the personal tax regime has begun only relatively recently.
\end{abstract}

This paper is based on work undertaken for the Department of the Environment, Transport, and the Regions, and the Inland Revenue of the United Kingdom Government, which is currently working on addressing this very issue. In addition to reporting the British situation, it also uses a series of case studies to outline how this same process has been approached in the United States, Ireland, Germany, Netherlands, Switzerland and Norway, and at how successful they have been thus far with respect to TDM objectives. It then draws conclusions as to which direction policy makers should be aiming for in the future.

* Corresponding author. 
Potter, Enoch, Rye, Black and Ubbels

\section{Tax and Transport Policy}

In recent years there have been increasingly strong linkages between national fiscal systems and environmental and transport objectives. This initially involved the ‘eco-reform’ of existing tax instruments, but the policy agenda has since moved on towards additional and replacement tax measures. Such policy developments are most advanced in Europe and some Pacific Rim nations, but have yet to have a serious impact in the Americas. Within the European Union (EU) the policy of the European Commission (EC) has been outlined in documents such as 'Towards Fair and Efficient Pricing' (CEC, 1995), and 'Fair Payment for Infrastructure Use’ (CEC, 1998), which broadly advocate that transport infrastructure charges should normally reflect the marginal social costs at the point of use. These marginal social costs should include not only marginal wear and tear costs on infrastructure, but also 'external' costs imposed on society, the environment and the wider economy through accidents, pollution, emission of climate change gasses, congestion etc.. While regulatory and physical design mechanisms are also recognized as having an important role to play, in the long run it is tax and charging instruments that the EC sees as being most effective at encouraging efficient and sustainable transport systems.

This economic argument is well known, but practical application is another matter. When moving from economic theory to tax policy there are a number of crucial design issues. Firstly it is important to target the measure to where it has impact. There are three major groups of transport taxation:

- $\quad$ Purchase of vehicles

- $\quad$ Ownership of vehicles

- $\quad$ Use - fuel and employer-provided transport benefits

Tax measures aimed at these three groups will have different impacts. For instance, if the policy aim is to green the vehicle fleet (e.g. promote fuel efficient cars or promote alternative fuels) then the first two groups are crucial. In terms of purchase measures, most EU countries have a specific car purchase or registration tax, which in some cases has been reformed to favour cleaner vehicles (Van den Branden, 2000, Potter et al 2005). In Finland, for example, there is a reduction for low emission vehicles. The Netherlands has a system of allowances against a standard car purchase tax of $45.2 \%$. This tax rate may seem high (although at 105\% Denmark's is higher), but is reduced by the counterbalancing tax reductions. This is $€ 1,540$ (about \$US2,000) for petrol and LPG cars, $€ 580$ (\$US770) for diesel cars, with other allowances for cleaner vehicles. Thus the fixed tax reduction cuts the tax charge significantly for smaller and more fuel-efficient cars and raises the price of larger and less fuel-efficient vehicles.

Germany and the UK are unusual in that they have no car purchase tax. The UK did, until 1991, have a Car Purchase Tax of $10 \%$ on five-sixths of the list price value of a new car. This was reduced to $5 \%$ in 1991 and abolished altogether in 1992. It was replaced by the UK policy for higher fuel duty, whereby 
Potter, Enoch, Rye, Black and Ubbels

up to 2000, fuel duties rose higher than the rate of inflation. In June 2004, France announced plans to reform of their car registration tax into a 'feebate' scheme. Cars that emit over $180 \mathrm{~g} / \mathrm{km}$ of $\mathrm{CO}_{2}$ or diesels without a particulates filter will pay a surcharge of $€ 1,500$ - $€ 3,500$ (\$US2,000 - \$US4,600), with a rebate of $€ 200$ to $€ 700$ ( \$US260-\$US920) for cars that emit under $140 \mathrm{~g} / \mathrm{km}$ of $\mathrm{CO}_{2}$ and diesels with particulate filters (Henley 2004). Cars in the middle, emitting between 140 and $180 \mathrm{~g} / \mathrm{km}$ of $\mathrm{CO}_{2}$ will be liable to neither a surcharge nor rebate.

Ownership/use measures can have influence upon vehicle choice if they are highly graded. Most developed economies have a graded annual registration (or 'circulation') tax, entitling the owner to drive a car on the public highway. In the USA and some other countries this takes the form of a 'number plate' tax. This longstanding tax is often varied by engine size or power of a car, but some nations have introduced an eco-reform to this tax. In Denmark the tax varies with fuel consumption, whereas Germany links the tax liability directly to the Euro emission standards, with the least polluting car paying only $20 \%$ of the rate of the most polluting car. However, the overall level of the tax is so low (only about $€ 50 / \$ U S 70$ per car), that its impact on car choice is negligible. From 1999, the UK progressively changed from a fixed-rate annual registration tax, and from 2001 adopted a $\mathrm{CO}_{2}$ emission-based system in four bands (A-D), with the charge varying from $£ 100$ - $£ 160$ (\$US180\$US290. Alternative fuel cars are evaluated on the same bands, but have a slightly lower charge of between $£ 90$ - $£ 150$ (\$US160-\$US270). In 2003 two further bands were added for very low $\mathrm{CO}_{2}$ emission vehicles, with the charge range widened to $£ 55$ - $£ 165$ (\$US100 - \$US300). However, this is a relatively small tax and does not appear to have exerted a significant influence upon car purchase decisions

The car use measure that has resulted in a change in purchasing decisions has been the UK's reform of company car taxation, which took effect from 2002. This is the annual tax bill for people whose employer provides them with a car for private and commuting use as well as business purposes and can amount to thousands of pounds per annum. The tax is an assessment of the private benefit of this 'benefit in kind'. From 2002 the tax charge on company cars has varied according to the level of the car's $\mathrm{CO}_{2}$ emissions, building up from 15\% of the car's price, for cars emitting 165 grams per kilometre ( $\mathrm{g} / \mathrm{km}) \mathrm{CO}_{2}$, in $1 \%$ steps for every additional $5 \mathrm{~g} / \mathrm{km}$ over $165 \mathrm{~g} / \mathrm{km}$. The maximum charge is on 35\% of the car's price. Diesel cars not meeting Euro IV emissions standards incur an additional charge of $3 \%$, up to the $35 \%$ ceiling. There are further reductions for company cars using cleaner fuels and technologies.

This reform has affected the use and type of cars within the UK company car fleet. In the first year of the new system the number of business miles was reduced by over 300 million miles per year and the average $\mathrm{CO}_{2}$ emissions of new company cars decreased from $196 \mathrm{~g} / \mathrm{km}$ in 1999 to $182 \mathrm{~g} / \mathrm{km}$ (Inland Revenue, 2004).

To promote behavioural change through modal shift, the third group is by far the most important. The level of fuel taxation can affect both the type of cars driven (e.g. by providing incentives for smaller 
Potter, Enoch, Rye, Black and Ubbels

engine sizes, or 'greener fuels') and, by the general level of taxation on motor fuels raising prices, influence modal choice and the volume of travel.

The extent to which the price of fuel is an effective tool to influence modal choice has been the subject of some contention. Joseph (2000) noted that rises in traffic levels in Britain over the decade to 2000, during which time there was a policy to increase road fuel duty in real terms, had been relatively low, despite levels of economic growth that have previously stimulated significant traffic growth. Bates et al (2004) have modelled the possible effect of fuel duty on congestion and state that "to keep [traffic] demand at its present levels and therefore congestion on average no worse than it is now, would require motoring charges or tax to be five times the current level of fuel duty, an annual increase of $6 \%$ every year (the same rate of increase as the fuel duty escalator which led to the fuel duty protests after only a few years)” (p 5).

Joseph considered the key difference between economic growth generating high car traffic growth in the past and not doing so now was the impact of high fuel prices. It is likely that, as well as fuel prices, capacity constraints in the UK are also playing a role in slowing traffic growth. In general there is concern that a single policy measure can be ineffective and that the effects of the taxation system upon modal choice requires a more comprehensive approach and understanding. This issue is discussed in detail in the European Council of Ministers of Transport report 'Internalising the Social Costs of Transport' (ECMT, 1997), which advocates a synergistic mix of taxation and charging instruments, including a number of local targeted mechanisms, such as road user pricing. Broadly the view is taken that a carefully designed mix of various economic instruments (see Table 1) and regulations is needed to achieve political acceptance and practicality.

\section{TABLE 1 Vehicle, Fuel and Traffic Market-Based Incentives (ECMT, 1997)}

These studies suggests that simply raising the tax rate of existing fiscal measures may not be the most efficient way to address environmental and transport policy objectives. This was because the tax measures had not been designed to do this. The argument that a different transport taxation regime is needed is reinforced by growing political pressures. For instance transport taxation in the United Kingdom, particularly upon fuel, is an increasingly controversial subject. There is a widespread perception that the motorist is simply a convenient source of revenue and that the environmental justification of taxation is little more that a matter of presentation. This led to the autumn 2000 'fuel protests', which featured elsewhere in Europe, with the UK alone reducing annual automobile and truck taxation by nearly $£ 2$ billion ( $\sim$ US3 billion). The UK and other European governments are now very wary of simply charging higher rates for exiting transport tax measures.

Thus, well before they have reached an economic 'fair and efficient' level, existing vehicle and fuel taxation measures have hit serious barriers, which politicians do not appear to have the stomach to tackle. Is there some way around this impasse? One way is to shift the focus from the vehicle and fuel taxation regime to that of the personal taxation regime. This has been much neglected in terms of the transport pricing issue, and could offer a way forward. Indeed, the need to move towards a more 
Potter, Enoch, Rye, Black and Ubbels

holistic, and systems-based approach in using the taxation system to promote more sustainable transport modes requires a consideration of the role that personal taxation measures can play. Can personal taxation complement vehicle and fuel taxation to make the whole system more effective, more equitable and more politically acceptable? This paper looks at the relationship between changes to the personal tax regimes and transport behaviour. Specifically, it looks at the tax treatment of commuting expenses and employer support for the journey to work in Germany, Netherlands, Switzerland, Norway, the United States, the UK and Ireland.

\section{Transport/ Environmental Policy and the Personal Tax System}

It is upon commuting trips that any reforms to the personal taxation system will have their largest effect. According to the UK National Travel Survey, commuting accounts for about $20 \%$ of all personal travel. The personal tax regime can also influence business trips, which account for another $10 \%$ of travel, so overall such tax measures could impact upon about $30 \%$ of travel volume. For transport policy, commuting and business trips are also important as they form a high proportion of peak hour travel.

Historically, the tax treatment of commuting and business travel expenses and employer support for the work journey has evolved with no reference to transport objectives, but in recent years a number of countries have taken transport/environmental objectives into account in the reform of this part of the personal taxation system.

The tax treatment of commuting expenses and employer support for the work journey varies between countries, and a comprehensive review of this issue for EU member states features in a report to the European Commission (Van den Branden et al, 2000). In summary, the study highlights the contrast between countries who view commuting as a personal expense. These include the UK, Austria, Greece, Ireland, Italy, Portugal and Spain (and also the USA). Others, including Belgium, Denmark, Finland, France, Germany, Luxembourg and the Netherlands, view commuting as a tax deductible expense. With respect to transport and environmental policies, this report notes lessons with both types of system. The report concludes that most taxation regimes provide contradictory signals regarding 'greener' forms of transport. However, some countries that have started from both standpoints have recently sought to use elements of their personal taxation system to encourage the use of more sustainable transport modes. Major examples of these are detailed below.

\section{Commuting as a tax-deductible expense}

This section examines the examples of Germany, the Netherlands, Switzerland and Norway. 
Potter, Enoch, Rye, Black and Ubbels

\section{Germany}

In Germany, tax relief for commuting to work can be claimed in one of two ways (Smith, 1995). Individuals can claim either:

- $\quad$ A lump sum deduction, or

- A deduction based on the actual cost of public transport or a mileage rate for a car.

Until 1988, the car rate was DM0.36 ${ }^{1}$ per kilometre $(\mathrm{km})$ ( 16 US cents per km), which was higher than marginal costs, but lower than total costs (including capital etc.). In 1990 this was increased to DM0.50 per km (22 US cents per km), but at the same time fuel taxes were raised which roughly counterbalanced the increase. The use of public transport for commuting could also be claimed, but most people declared they commuted by car because it was more tax advantageous to do so. From 1992, there has been a special tax exemption for employer-provided 'Job Tickets' for use on public transport in some areas of Germany.

As of 2001, a combined rate of DM0.70 per km (31 US cents per km) was introduced for all modes of transport. Smith notes an acceptance that, despite the special 'Work Ticket' provision, the German tax concessions on commuting costs has encouraged long distance commuting and stimulates work journeys by car rather than public transport. This is partially due to car users perceiving the costs of driving as fuel costs alone. Thus they feel that they can 'make money' on the tax concessions over and above their expenditure if they drive to work, which they cannot do if they use public transport. The 2001 reform may reduce this imbalance somewhat, but will not address the commute trip lengthening issue.

In Germany, tax relief on commuting costs is long established and Smith noted that (at the 1990 rates) it costs the German Government (depending on the calculation method used) between DM1.8 billion and 4 billion (\$US800m - \$US1,760m) per annum in lost revenue. Overall, Germany appears to suffer the worst of both worlds; the Finance Ministry is making a major tax concession on commuting costs and the transport and environmental impacts of this fiscal measure are entirely negative.

\section{Norway}

Norway operates a similar regime to Germany, with a deduction for commuting expenses of 1.40 Norweigan Kroner (NOK) (22 US cents) per km irrespective of means of transport. In addition, car users can claim ferry and road tolls; if air travel is used for weekly commuting the actual costs can be deducted. However, if commuting costs are only deductible if they exceed 7,000 NOK (\$US1,120); this

\footnotetext{
${ }^{1}$ Currency exchange rates for pre-Euro currencies are converted into US Dollars using 2001 conversion rates. Currently existing currencies are calculated using exchange rates cited in XE (2004).
} 
Potter, Enoch, Rye, Black and Ubbels

equates to a journey to work distance of about $15 \mathrm{~km}$ before a commuting becomes tax deductible. This tax regime produces much the same problems as the German system, indeed, the minimum threshold provides an incentive for employees to live further from work in order to cut their tax liability.

\section{Netherlands}

In the Netherlands, the general principles of fiscal policy are similar to those of many other countries: lowering tax rates is a key long-term goal, within which are policies to broaden and strengthen the tax base; to green taxes to promote sustainable economic growth and to simplify the tax system. Taxation and Travel Planning (also known as vervoermanagement in the Netherlands, TDM in the USA, and Mobility Management by the EC) are closely related to the second two of these principles. Equity is also an important consideration.

Interestingly, for many years the Dutch commuting tax position gradually evolved year by year as policy began to favour alternative travel options to the car, a situation that led to an increasingly complicated structure. Accordingly, in 2002 the Netherlands Ministry of Finance radically overhauled the commuting benefits system, partly to simplify the system, and partly to further promote the use of alternative modes. The taxation of commuting travel in the Netherlands is based on two benefits. These are:

- the reiskostenvergoeding (reimbursement from the employer of an employee's commute costs, normally paid only to those who travel more than $10 \mathrm{~km}$ one way); and

- the reiskostenforfait, the allowance for travel costs paid by the employer to the employee which he/she can then offset against tax.

The degree to which the reiskostenvergoeding is taxable, and the size of the reiskostenforfait, both vary depending on the mode used. In addition, if no reiskostenvergoeding is paid (more common in public sector organizations), then the employee is able to write off a portion of their commuting costs against tax. The precise amount is, again, related to the mode used. In general, the tax regulations have been changed in order to favour the use of more sustainable modes. These arrangements were subsequently slightly adapted in September 2004, when two important changes were introduced (SVNH, 2004). Firstly, commuting traffic is now treated in the same way as business traffic, meaning that employers can compensate employees for their travel costs with a fixed reiskostenvergoeding of $€ 0.18 / \mathrm{km}$ (23 US cents) no matter what type of vehicle is used. Secondly, tax-free compensation for telecommuting has been abolished. Previously, this had meant that an employer could make a tax-free 4000 NLG (\$US1,560) contribution to the employee to cover costs of setting up a home office over a five year period on the condition that the office is used at least once per week in lieu of a normal commuting journey and that there was a written contract between employer and employee. The other rules remain roughly the same as in 2002 and are described below. 
Potter, Enoch, Rye, Black and Ubbels

Car - when the employee uses its own car for commuting, the employer is allowed to give a reiskostenvergoeding of $€ 0.18 / \mathrm{km}$ (23 US cents) (independent of distance travelled). The same holds when these kilometres are made with a company car. In case the employee uses the company car for private reasons taxable income should be increased with $22 \%$ of the catalogue value of the car (in case more than $500 \mathrm{~km}$ are privately travelled). If less than $500 \mathrm{~km}$ are driven for private reasons (clearly appearing from trip registration) than one need not to increase income. Commuting kilometres are not private kilometres (these are classed as business). Employer provided parking remains untaxed, although employer provided expenses to compensate for parking expenses are taxed (if not included in the reiskostenvergoeding).

Carpooling - driver and car sharers can obtain a tax free compensation of $€ 0.18 / \mathrm{km}$ (23 US cents) for both private and company car. Any financial benefits of carpooling are not taxed.

Works buses - the use of transport provided by the employer (work buses, vanpooling) has no consequences for income taxation.

Public transport - there are two possible tax free ways to compensate employees for their commuting costs when travelling by public transport (reiskostenvergoeding):

Payment of the true costs

Kilometre compensation of $€ 0.18$ (23 US cents) (tickets need not to be administered).

These guidelines also hold for business traffic by public transport. For instance, if a season ticket specific to the employee's trip from home to work is provided by the employer, this is completely taxfree to the employee, even if s/he commutes only infrequently by public transport. If a non-routespecific ticket (e.g. an area-based Travelcard) is provided, tax is payable on an assumed value for private use. This value is $€ 54$ (\$US70) per year for second class and $€ 82$ (\$US107) for first class passengers.

Finally, if an employee uses public transport and does not receive one of the previous compensations, then providing s/he commutes for at least $10 \mathrm{~km}, \mathrm{~s} / \mathrm{he}$ can decrease his/her level of taxable income with a sum of money calculated according to the distance of a single trip - not on actual costs.

Bicycles - The employer is allowed to provide a tax free payment for commuting by bike of again $€ 0.18 / \mathrm{km}$ (23 US cents). Employers are also allowed to provide employees with a new bike, but only once every three years. The value of this bicycle is treated as income, but if ite is used for commuting, the value of the bike is fixed at $€ 68$ (\$US89) for tax purposes. This applies to bikes up to a maximum value of $€ 749$ (\$US976). Employers may also providebike accessories (e.g. maintenance, clothing locks etc.), this is tax free up to a value of $€ 250$ (\$US326).

Overall, the taxation system in the Netherlands has started from a similar position to Germany, but the Dutch government has managed to introduce a series of reforms across a wide range of taxation 
Potter, Enoch, Rye, Black and Ubbels

specifically designed to favour 'greener' modes of travel. Thus TDM measures introduced by employers are exempt from negative tax impacts, or are actually enhanced by the taxation system. Following an initial round of tax reforms, the Dutch government has realized that, rather than adding on transport and environmental considerations to existing tax measures, they needed a major reform of the whole tax system itself. This evolution in tax policy should be noted. By linking transport tax 'sticks' to both transport tax and general tax 'carrots', they have achieved a radical reform that has eluded most other countries.

\section{Switzerland}

Switzerland has a tax situation somewhat between Germany and the Netherlands. Commuting is a taxdeductible expense, but the tax rules are designed to provide an incentive for travel by public transport rather than car. For travelling by public transport the actual costs may be set against tax. There are 'standard deductions' for car users, but their use is restricted. The baseline position is that individuals, whether they use car or public transport, can only deduct the cost for the use of public transport. A case has to be made (e.g. the taxpayer lives too far from a station, their work requires them to travel at unsuitable times or they have a physical handicap) to claim a standard car deduction. According to $\mathrm{Mr}$ G. Steinmann, of the Office for Legislation Federal Direct Tax (personal communication), the Swiss Government plans "to examine more deeply the tax treatment of commuting and business transport expenses, and in particular to focus on the deduction of costs for car commuting”. This will form part of a planned ecological tax reform, which may follow the Dutch model.

\section{Summary}

In the countries where commuting is a tax-deductible expense, there have been moves (some significant) to increase general benefits for more sustainable modes relative to less sustainable methods of travel. However, the use of such general concessions appears to have stimulated car commuting and trip lengthening, and reducing benefits to car commuters is politically very difficult. In most cases the environmental and transport impacts are entirely negative. The Dutch reforms, linking changes to the treatment of transport tax benefits to wider taxation reform, seems to be the only model that has produced significant progress.

\section{Commuting as a non-tax-deductible expense}

\section{The USA}

Under the USA taxation system the cost of travelling between home and work is not an allowable tax deduction and any employer provision is viewed as taxable income in kind. However, in recent years exemptions have been made. In contrast to the blanket tax concession of Germany and the wide range of generally pro-public transport and bicycle measures in the Netherlands, in the USA, tax concessions 
Potter, Enoch, Rye, Black and Ubbels

are specifically for company TDM measures. This began during the mid-1980s with further enhancements and developments added over time to produce a raft of targeted exemptions.

Policy in the USA reflects the research conclusion that "direct financial incentives or subsidies are a key element of successful programs" to reduce single car occupancy travel to work. This conclusion is based upon the monitoring of the effectiveness of various measures (Shreffler, 1999; Ligtermoet, 1998; TCRP, 2003). A summary of the history of Federal commuter benefits in the US is shown in Table 2.

\section{TABLE 2 Evolution of Federal Commuter Benefits in the United States (TCRP, 2003)}

Given that only 4.4\% all work trips were made by transit in the USA in 2003 (BTS, 2004), a major part of these tax concessions has been for vanpools as well as for public transport. Indeed outside major cities, transit services may simply not exist, whereas setting up vanpools would be more viable.

The provisions of the 1992 National Energy Policy Act forms part of the Internal Revenue Code, whereby, as of January 1993 employers can provide each employee commuting on transit a benefit up to an initial limit of \$US60 per month (\$US720 per year) which is tax deductible to the employer and tax free to the employee. The Energy Policy Act included adjusting the limits with inflation, rounded to multiples of \$US5. From August 1998, the Transportation Equity Act for the 21st Century (TEA-21) allowed employers and employees to share the tax benefit, a key factor that has increased growth in use of transit benefit. For example, sales of transit vouchers by Commuter Check Services Corporation, the operator of Commuter Check, one of the major operators of such benefit services in the US, were reported to be increasing at a rate of $10 \%$ per month in 1999, compared to $2 \%$ per month in 1998 , prior to the TEA-21 changes (IBI Group, 1999). Employers do not have to contribute anything to the cost of their employees’ public transport costs but employees still benefit. Certain employers limit their involvement in this way, whilst others make a (tax-free) contribution on behalf of their staff. The concession (up to the maximum limit) covers (US Government, 1992):

- Transportation in a commuter highway vehicle if such transportation is in connection with travel between the employee's residence and place of employment.

- Any transit pass.

- Qualified parking.

- A 'commuter highway vehicle' covers schemes involving private bus pools, shuttles, subscription bus services and vanpool leasing. The ‘qualified parking' is for the commuter highway vehicles only, up to a value of \$US155.

The Taxpayer Relief Act of 1997 and the 1998 Transportation Equity Act for the 21st Century have extended these measures to the cashing out of employer-provided parking up to the \$US65 a month ceiling. This Act also provided for increasing the non-taxable transit and vanpool benefit ceiling to 
Potter, Enoch, Rye, Black and Ubbels

\$US100 a month as of 1st January 2002, with the resumption of increases indexed to inflation. In addition, parking 'cash out' payments are now tax exempt. This is part of the move in the USA away from regulations requiring employers to introduce Travel Plans, to an approach encouraging the voluntary take-up of Travel Plans (as is the policy in the UK). Targeted tax relief to the treatment of the most effective Travel Plan measures is a key part of this. The benefits and the options available for implementing them are summarised in Table 3.

\section{TABLE 3 Summary of Tax Options and Benefits for Employer TDM Measures in the United States (BEST Workplaces for Commuters, 2005)}

To facilitate the provision of transit benefits a new TDM services industry has emerged. An example is the TransitChek scheme, used in New York and elsewhere in the USA. Here, more than 14,000 employers purchase Metrocard passes and/or vouchers from the New York TransitCenter, an alliance of transit operators that administers the programme for the region which was first established in 1986. These cards and/or vouchers are then distributed to employees. Interestingly, the scheme is marketed as a staff benefits package rather than a transport programme (TransitCenter, 2005). In evaluating the scheme, Litman (1997) noted that around 25\% of the TransitChek recipients previously commuted by car alone. A small amount (about 4\%) were previously car passengers and about 2\% previously walked. In the USA context he saw this as a good result. He suggested that a higher uptake by car drivers could be expected in places with a better public transport infrastructure and where companies linked TransitCheks to Travel Plans.

\section{United Kingdom}

As in the USA, in the UK the cost of travelling between home and work is not an allowable deduction for the purposes of assessing employees Income Tax or state pension (National Insurance) contributions. There are a few clearly defined exemptions to this. The main example is employerprovided car parking for commuters. Technically, until 1999 this exception related to car parking only, and free parking for bicycles, motorcycles or any other vehicles were taxable (although it was never taxed in practice).

A general statutory exception, which does not just relate to employer-provided transport benefits, regards company loans to staff. These can be used for any purpose, including, for example for the purchase of season tickets and bicycles, or for that matter, cars. Interest-free loans are not taxed subject to a limit of a $£ 5,000$ (\$US7,000) loan in a single tax year.

In 1999 a series of further reforms were introduced to tax treatment of Travel Plan (TDM) benefits specifically to encourage their uptake. In detail these reforms were that no tax would be liable on:

- Works buses of 12 or more seats (reduced to nine seats in 2002) used mainly to bring employees to and from work. 
Potter, Enoch, Rye, Black and Ubbels

- General subsidies to public bus services provided that the employees pay the same fare as other members of the public.

- Cycling safety equipment.

- Workplace parking for bicycles and motorcycles.

- Alternative transport for car sharers to get home in exceptional circumstances, such as working late, domestic emergencies etc.

In addition to these tax concessions, there was a change to the tax treatment of business travel in that the tax free mileage rate for employees using their own bicycle was raised to 7.5p per km (14 US cents per km), and if their employer provides no payment this can be claimed by the employee. This was subsequently increased to 12.5p per km (23 US cents per km) in 2002.

Shortly afterwards, the government issued guidance encouraging employers to adopt Travel Plans (DETR, 1998). These concessions leave within the tax net a number of direct incentives and possible disincentives that feature in some Travel Plans. This particularly applies to the measures proven to be most effective, such as any subsidies to public transport tickets for staff, to cash incentives to take part in a Travel Plan. While the British Government did consider altering the tax system to accommodate these issues prior to the 2001 Budget, it chose not to proceed beyond a few cosmetic changes, while at the same time cutting motoring taxes by £1.5 billion (\$US2.8 billion).

One issue to emerge from research in the UK is that tax concessions have been concentrated upon employees rather than their employer (Potter, 2003). If the employers do not offer a tax free benefit then the personal tax benefits to employees fail to arise.

\section{Ireland}

In Ireland, commuting is also not a tax-deductible expense, but from the tax year 1999/2000 a specific concession for employer-provided public transport support was made. Under the 1999 Finance Act benefits in kind by way of a monthly or annual bus or train pass are tax exempt. This is subject to an annual limit of £I696 (about \$US752).

While Irish public transport companies had lobbied on tax free season tickets for years without success, Phelan (2003) reports that the concession finally came about because prior to the 1999 Finance Act the Department of Environment wanted to push for an 'easy' measure and backed it so that it was successful. Essentially, the benefit could be given as a bonus or instead of a new pay increment, with the item made tax free (i.e. it was no longer counted as being a benefit in kind), while the public transport pass had to be monthly or annual. But, these terms were extremely restrictive and very difficult to administer. Indeed, even the Irish Civil Service found it too complex to apply it for its staff. This complexity was a result of the concession being introduced at the same time as one for crèche 
Potter, Enoch, Rye, Black and Ubbels

facilities - any change in the wording in the Act for the season tickets would set a precedent for the far more 'expensive' childcare discount.

Following more intense lobbying, in September 2000 a revenue briefing document quietly altered the interpretation of the Act so that people can now request to forgo part of their salary (rather like for pensions) (Irish Revenue, 2000). As a result, uptake of the benefit increased dramatically in December 2000 when the Civil Service joined the scheme.

Overall, the system is now workable and the Benefit-In-Kind approach is now seen as superior to the alternative system of tax relief (like health insurance based on PAYE) so a company would 'pay' €600 (\$US781) for a ticket and then claim tax relief the following year. For a start, people would have had to keep tickets and then submit them, while tax credits at source would need to be administered by the public transport companies, who would therefore require knowledge of the person's tax rate and so on not an ideal role for a bus company! In practical terms, tickets can be bought by companies from agents or wherever and claim back, or from public transport companies direct. Only monthly and annual passes are used, meaning that the tickets are non transferable.

At an organizational level, the scheme is administered in different ways. One company, a bank, gives an annual ticket in place of part of a monthly cheque (so if a wage was $€ 1,000$ (\$US1,300), it would give an $€ 850$ (\$US1,106) annual ticket plus $€ 150$ (\$US195) pay). Most companies though, pay the public transport company up front and then reclaim the money from the employee month by month, although some companies provide the ticket in a bonus package.

In terms of impact, the Irish Revenue underestimated the tax take. Meanwhile it has so far been extremely difficult to calculate the uptake in public transport ridership, although the take up in companies tends to be about $10 \%-15 \%$. It is also the case that most of the take up has occurred in the Dublin area, where a booming economy during the late 1990s led to higher employment and worsening congestion, which coupled with a significant improvement to the public transport system (through Quality Bus Corridors in particular) meant that far more people are prepared to travel by alternative modes to the car (Enoch, 2003). Initially it was expected that some companies to contribute to the cost of a ticket but this has not really happened on a large scale. The benefit is also seen as a good retention benefit for some smaller employers.

As in the USA, this tax concession has provided the opportunity for public transport operators to promote ticketing products. In the Dublin area publicity material under the title 'Easi-Travel Plan' is used to promoted to employers as a new 'Tax efficient incentive for your staff'. In addition to the tax efficiency, there is a $12 \%$ discount for employer purchase of travel passes for their staff. The annual allowance is sufficient to cover all types of public transport tickets in the Dublin area - a combined bus/rail ticket for the entire area costs $£$ I525 (\$US567). 
Potter, Enoch, Rye, Black and Ubbels

\section{Summary international cases}

From the above cases, a different approach is evident in countries where commuting has not been a deductible expense. The concept of introducing a general tax concession for all commuting by more sustainable modes has not featured. Instead there have been far more targeted measures upon employer-provided support. These include incentives to encourage the use of public transport, vanpooling and parking cash-out measures in the USA, and tax exemption for employer provided public transport passes in Ireland.

\section{Evaluating the Impact of Tax Reforms}

It is clear that a number of countries are adapting personal taxation measures to promote commuting by more sustainable forms of transport. However, there seems to have been little evaluation of the impact of these measures. As part of a UK government study examining the case for such tax reforms (Potter et al 2001), the authors of this paper sought to develop a method to evaluative the cost effectiveness of such reforms. The main reforms considered were:

\section{'Contract Carriage’ of employees on Public Transport, Community Transport and by}

Taxi/Minicab. Where employers enter into a contract with public transport operators to transport their staff to work

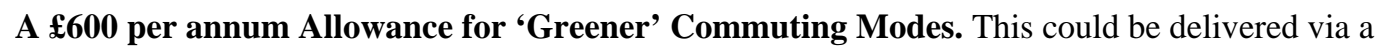
Travel Voucher system (like the USA transit checks), whereby employers could issue vouchers up to the agreed limit to their staff to pay for commuting by several greener forms of transport.

A $\mathbf{6 0 0}$ per annum parking cash-out exemption. Rather than providing a tax allowance on specified 'green' forms of travel, an alternative way would be to permit employers to pay staff a tax-free travel allowance if they also charge for parking at the same rate. Thus employees who do not park at work, for whatever reason, will retain the allowance or a balance of it.

A General Income Tax Concession of up to $£ 600$ per annum on the cost of public transport tickets.

Because of the lack of information on the impact of specific tax measures, more general studies of Travel Plan effectiveness and demand elasticities were used and estimates made of how the tax measures affected an overall Travel Plan. This produced likely modal shift impacts, which could then be compared to the cost to the Treasury of the various measures (with uptake estimates based upon the various international and UK studies considered in this paper). This permitted the calculation of the cost per single occupancy car trip diverted, which could be compared to the cost of other policy initiatives. The results are shown in Table 4. 
Potter, Enoch, Rye, Black and Ubbels

\section{TABLE 4 Tax Cost and Cost Effectiveness of the main reform proposals (Potter} et al, 2001)

In terms of cost per car trip diverted, the shared taxi scheme came out well. Both Travel Vouchers and the Contract Carriage proposals came next in terms of cost effectiveness, with the former having a wider impact. Travel Vouchers could be preferred for integrated transport policy reasons to tax relief on travel passes and season tickets, which in any case proved less cost effective. Parking cashout could be as (or more) cost effective as any of the above measures, but the study showed this to involve a degree of financial and operational uncertainty. General tax relief on public transport season tickets and passes was the least focused and most costly all round. Overall the more targeted tax concessions were estimated to be more cost effective than other policy options to effect modal shift, such as investment in light rail systems. In practice, the government acted upon the results of this study by implementing in 2002 a variation of the contract carriage concession, but restricted to local bus services.

\section{Key Conclusions}

Several observations can be drawn from the findings.

A general tax concession for all commuting trips creates negative transport and environmental impacts, as it tends to stimulate car commuting and trip lengthening. Furthermore, a general tax concession is also costly to the state concerned and not very cost effective compared with other tax measures.

While it is possible to focus a general tax concession upon public transport commuting trips, this can still contribute to trip lengthening producing negative environmental and traffic impacts.

The Dutch example of simplifying the commuting concession to more sustainable modes as part of a general tax reduction strategy indicates an advanced level of fiscal/environmental policy integration. As part of such a strategy, the concept of tax loss becomes irrelevant as the aim of policy is to target tax cuts.

In countries where commuting costs are not tax-deductible, targeted tax concessions upon employerprovided Travel Plan benefits have featured. These have been intended to support the development of effective Travel Plans and stimulate the use of particularly effective measures in influencing modal shift.

Tax concessions for employers are needed as well as those for employees. The corporate taxation system has much untapped potential.

Overall minor tinkering with a taxation regime, whatever the starting point, will not do much to address transport and environmental objectives, and may well have negative results. The most effective strategy is not to add on eco reforms to an otherwise unreformed taxation regime. If this is done they will largely be counteracted by other parts of the system, and are likely to be a politically weak part of that 
Potter, Enoch, Rye, Black and Ubbels

system, prone to being abandoned or ignored (as occurred in the UK Budget of 2001). The key way forward is for environmental objectives to be incorporated as part of reorientation of the entire personal taxation regime, to stand aside the other strategic goals of equitable revenue raising and as an instrument of economic policy. Only then can the conflicts with these long-established functions of personal taxation be resolved and there be any hope of environmental reform being effective and acceptable to the taxpayer.

\section{Acknowledgements}

The research supporting this paper involved two projects sponsored by the European Commission's Transport and Environment Directorate and the UK Government Department of the Environment, Transport and the Regions (now the Department for Transport). Grateful thanks are also extended to those interviewed over the course of this research.

\section{References}

Association for Commuter Transportation, 1998, Money Saving Tools, Explanation of the Federal Tax Advantages for Employer-Provided Transportation Benefits, from the TDM Tool Kit.

Bates, J. et al, 2004, Motoring Towards 2050. RAC Foundation for Motoring, London, UK.

BEST Workplaces for Commuters, 2005, Commuter tax benefits: Implementing commuter benefits as one of the Nation's Best Workplaces for commuters, Research Report for Projects 68-W6-0029 and 2W-0693-NBLX, Office of Air and Radiation, US Environmental Protection Agency, Washington DC, January.

Bureau of Transportation Statistics, 2004, National Transportation Statistics 2004, Bureau of Transportation Statistics, US Department of Transportation, Washington DC.

Commission of the European Communities, 1995, Towards Fair and Efficient Pricing in Transport. Policy options for internalising the external costs of transport in the European Union. Green Paper. CEC, COM (95) 691, Brussels.

Commission of the European Communities, 1998, Fair Payment for Infrastructure Use, White Paper, CEC, COM (98) 466, Brussels.

Department of the Environment, Transport and the Regions, 1998, The Benefits of Green Transport Plans, DETR, The Stationery Office, London.

Enoch, M. P., 2003, Getting the bus to work: Quality Bus Corridors in Dublin, Traffic Engineering and Control, 44(7), July/August, 252-254. 
Potter, Enoch, Rye, Black and Ubbels

European Council of Ministers of Transport, 1997, Internalising the Social Costs of Transport, OECD, Paris.

Henley, J. 2004, France launches radical green tax on bigger cars. Guardian Unlimited, 23rd June. Visit http://www.guardian.co.uk/france/story/0,1182,1245187,00.html. Last accessed 27 July 2004.

IBI Group, 1999, Tax Exempt Status for Employer Provided Transit Benefits, Final Report to the Canadian National Climate Change Process, Transportation Issue Table, chaired by Transport Canada, Ottawa, June.

Inland Revenue, 2004, Report of the Evaluation of Company Car Tax Reform, April 2004, Inland Revenue, London.

Irish Revenue, 2000, Benefit-In-Kind - Bus and Train Passes, Tax Briefing, 41, 22. Irish Revenue, Dublin, September. Visit http://www.revenue.ie/publications/taxbrefng/tb41.pdf. Last accessed 16 November 2004.

Joseph, S., 2000, Will Government Really Develop a Taxation System which Effectively Protects the Environment? - Challenges, Opportunities and Pitfalls. Paper presented at Queen Mary Westfield College Seminar Environment, Transport and Tax - developing the fiscal contribution to sustainability, London, 13 July. Transport 2000, London.

Ligtermoet M., 1998, Mobility Management in the Netherlands, Report to the Netherlands Ministry of Transport, Netherlands Ministry of Transport, Den Haag.

Litman T (1997) Employer provided transit passes: A tax exempt benefit, Victoria Transport Policy Institute, British Columbia.

Phelan J., 2003, Personal communication, Dublin Bus, Dublin, Ireland, 16 January.

Potter S., Enoch M. P., Rye T., and Black T. S., 2001, The Potential for Further Changes to the Personal Taxation Regime to Encourage Modal Shift, Final Report to the Department of the Environment, Transport and the Regions and the Inland Revenue. The Open University, Milton Keynes, June.

Potter, S: 2003, The potential of further tax reforms to support cycle commuting. Research Paper for the Department for Transport, The Open University, Milton Keynes.

Potter, S., Parkhurst, G.,and Lane, B., 2005, forthcoming, Towards a new fiscal framework for transport, Chapter 14 in Reggiani, A and Schintler, L (Eds): Methods and Models in Transport and Telecommunications: Cross Atlantic Perspectives. 
Potter, Enoch, Rye, Black and Ubbels

Shreffler, E. N., 2001, What Makes for Successful TDM Programs?, Louisville-Southern Indiana Ohio River Bridges Project, October. Visit http://www.kyinbridges.com/researchofdemand.htm. Last accessed 31 July 2001.

Smith S., 1995, 'Green’ Taxes and Charges: Policy and Practice in Britain and Germany, The Institute for Fiscal Studies, London.

Stichting Vervoermanagement Noord-Holland, 2004, Fiscale Regelingen 2004, Stichting

Vervoermanagement Noord-Holland, Amsterdam. Visit http://www.verkeeradvies.nl. Last accessed 9 November 2004.

Transit Cooperative Research Program, 2003, Strategies for increasing the effectiveness of commuter benefits programs, Report 87, Transit Cooperative Research Program, Federal Transit Administration, Washington DC.

TransitCenter (2005) Making commuting more affordable nationwide, TransitCenter, New York City. Visit http://www.transitcenter.com. Last accessed 25 May 2005.

US Government, 1992, National Energy Policy Act, Section 1911, Washington DC.

Van den Branden, T., Potter S., Enoch M. P., and Ubbels, B. J., 2000, Fair And Efficient Pricing In Transport - The Role Of Charges And Taxes. Report for European Commission DG TREN, Oscar Faber, Birmingham, England.

XE, 2004, Universal Currency Converter Results. Visit http://www.xe.com. Last accessed 16 November 2004. 


\section{List of Tables}

TABLE 1 Vehicle, Fuel and Traffic Market-Based Incentives

TABLE 2 Evolution of Federal Commuter Benefits in the United States

TABLE 3 Summary of Tax Benefits for Employer TDM Measures in the United States

TABLE 4 Tax Cost and Cost Effectiveness of the main reform proposals 
Potter, Enoch, Rye, Black and Ubbels

TABLE 1 Vehicle, Fuel and Traffic Market-Based Incentives (ECMT, 1998))

\begin{tabular}{lll}
\hline & Direct & Indirect \\
\hline Vehicle & Emission Fees & Tradable permits \\
& Differential vehicle taxation \\
Fuel & Tax allowance for new vehicle \\
Traffic & Differential fuel taxation \\
& Fuel taxes \\
& Congestion charges \\
& Parking charges \\
\hline
\end{tabular}


Potter, Enoch, Rye, Black and Ubbels

TABLE 2 Evolution of Federal Commuter Benefits in the United States (TCRP, 2003)

1984: Deficit Reduction Act - \$US15 per month tax exemption for transit users, with restrictions

1991: IRS administrative action - increased monthly transit cap to \$US21

1993: National Energy Policy Act - Added Internal Revenue Code, Section 132(f) ‘Qualified Transportation Fringe'

- $\quad$ Vanpool expenses also qualified

- $\quad$ Transit/Vanpool benefits - to \$US60 per month

Qualified Parking - \$US155 per month

1996: IRS indexing of benefits

- Transit/Vanpool benefits - \$US65 per month

- Qualified Parking - \$US165 per month

1997: Taxpayer Relief Act - taxable payments in lieu of employer provided parking permitted

1998: Transportation Equity Act For the $21^{\text {st }}$ Century (TEA-21)

Employee can elect to buy transit fares with pre-tax compensation

Tax-free transit benefit increases to \$US100/month after 2001

2001: Final Regulation: Qualified Transportation Fringe Benefits 
TABLE 3 Summary of Tax Options and Benefits for Employer TDM Measures in the United States (BEST Workplaces for Commuters, 2005)

\begin{tabular}{l}
\hline Option \\
\hline Employer paid: Employers \\
provide employees with up to \\
$\$ 105 /$ month to commute via \\
transit or vanpools (typically \\
through passes or vouchers) \\
and/or up to $\$ 200$ a month to \\
pay for parking.
\end{tabular}

\section{Employee Pre-Tax}

Deduction: Employers allow staff to reserve up to $\$ 105 /$ month in pre-tax income to pay for transit or vanpools and/or up to $\$ 200 /$ month to pay for parking.

\section{Employee, Employer Share Costs: Employers pay transit, vanpool or qualified parking costs up to a certain limit and the employee pays for the remainder of the costs through a pre-tax deduction. Total employer and employee paid costs cannot exceed the monthly limits of \$105/month for transit and vanpool and \$200 for qualified parking.}

\author{
Employer Tax Benefit $\quad$ Employee Tax Benefit
}

Compared to providing a salary increase, the employer saves on payroll taxes. No payroll taxes are paid on the value of the benefit.

Employer saves on payroll taxes. No payroll taxes are paid on the income that is reserved by the employee.

Employer saves on payroll taxes on the portion of the subsidy paid by the employee through a pre-tax deduction, and on the value of the benefit provided to the employee compared to providing a salary increase.
Employee receives up to \$105/month tax-free to commute via transit or vanpool (and \$200/month tax-free for qualified parking). The employee does not pay any taxes on the value of the benefit.

Employee saves on income tax and payroll taxes. The amount of the benefits is no longer treated as taxable salary.
Employee does not have to pay any taxes on the portion of the benefit provided by the employer. Additionally, the employee saves on income tax and payroll taxes by taking a pre-tax deduction to pay for the remainder of his/her commuting costs. 
Potter, Enoch, Rye, Black and Ubbels

TABLE 4 Tax Cost and Cost Effectiveness of the main reform proposals (Potter et al, 2001)

\begin{tabular}{llll}
\hline Tax measure & $\begin{array}{l}\text { Cost per single } \\
\text { occupancy car trip } \\
\text { diverted }\end{array}$ & Tax cost & $\begin{array}{l}\text { Likely Uptake (\% of } \\
\text { employees offered } \\
\text { benefit) }\end{array}$ \\
\hline Contract Carriage & $£ 140-£ 700$ & $£ 45 \mathrm{~m}$ & $5-10 \%$ \\
Travel passes & $£ 160-£ 800$ & $£ 7-£ 80 \mathrm{~m}$ & $10-20 \%$ \\
Shared Taxi & $£ 60-£ 300$ & $£ 2 \mathrm{~m}$ & $5-10 \%$ \\
Travel Vouchers & $£ 140-£ 700$ & $£ 9-\mathrm{c} £ 200 \mathrm{~m}$ & $10-20 \%$ \\
Parking Cashout & $£ 480-£ 2,400$ & $£ 56-£ 500 \mathrm{~m}$ & $5 \%$ \\
General Tax & $£ 1,000$ & $£ 880 \mathrm{~m}$ & $100 \%$ \\
Concession & & & \\
\hline
\end{tabular}




\section{Biographies}

\section{Dr Stephen Potter}

Stephen Potter is a Senior Research Fellow at the Open University. He has undertaken research, including for the UK Department for Transport and the European Commission, on fiscal measures to support TDM policies, including recommendations that have now become UK law. His transport research and teaching also covers innovative transit systems, the organisation of TDM policy implementation and measures to reduce transport's environmental impacts. As well as contributing to the Open University's degree and postgraduate courses, he has worked on training courses for transport professionals and the UK National Transportation Qualification.

\section{Dr Marcus Enoch}

Marcus Enoch has been a lecturer in transport studies at Loughborough University since January 2003, and has been involved in transport research for a number of organisations such as the European Commission, UK Department for Transport, UK Inland Revenue and a number of UK local authorities. In particular, Dr Enoch has undertaken research in a range of areas investigating the planning and implementation of mobility management policy measures including employer Travel Plans, parking policy, car clubs, Demand Responsive Transport Systems and buses. Dr Enoch has a BEng(Hons) in Civil Engineering from the University of Nottingham, an MSc(Eng) in Transport Planning and Engineering from the University of Leeds, and a PhD from the Open University.

\section{Dr Tom Rye}

Tom Rye has a BA in Geography from the University of Oxford, an MA in Community and Regional Planning from the University of British Columbia and a PhD in Transportation Demand Management from Nottingham Trent University. He has considerable experience of public and sustainable transport, through his work for London Transport Buses and London Transport Planning, through his research, which has taken him to the US, Germany and the Netherlands, and through a four year secondment to transport consultants Colin Buchanan and Partners. His key skills are in transport policy development, mobility management, public transport studies and objectives-based appraisal. He has published widely in the area of transport policy, notably in terms of implementation, transport demand management and public transport planning. He is currently a Reader in Transport Studies as part of the Transport Studies Group within the School of the Built Environment at Napier University, Edinburgh, Scotland; and also seconded part-time to the City of Edinburgh Council, where he is working on the development of an investment package to be funded from the City’s proposed congestion charging scheme. 
Potter, Enoch, Rye, Black and Ubbels

\section{Dr Colin Black}

Colin Black is Divisional Director responsible for Transport Planning in consultant JMP's London West-End office. He more than ten years experience leading transport-planning projects and is internationally recognised for his work on sustainable transport policy. He has presented a number of papers on the subject and has provided advice to a variety of UK and European research bodies. At JMP, Dr Black is currently providing advice for a range of major transport master planning and regeneration projects, and is experienced in developing sustainable transport strategies for a broad range of development types.

\section{Barry Ubbels}

Barry Ubbels graduated in 1997 in Transport and Regional Economics at the Free University Amsterdam, and joined the staff of the Department of Spatial Economics (Faculty of Economics) of the same University as a research associate. His research interests include a wide range of transportation and regional development issues, but with a particular emphasis on the pricing and financing of mobility and infrastructure, which he has conducted for several institutions including the Dutch Government, local authorities and the European Union. Besides this (more) applied scientific research work, Mr Ubbels is currently working on his PhD-research towards the effects of pricing policies on mobility behaviour in a multi-disciplinary context. 